\title{
Effects of Nickel, Zinc, and Lead-Contaminated Soil on Burrowing Rate and Coelomocytes of the Earthworm, Allolobophora chlorotica*
}

\author{
Agnieszka Podolak, Elzbieta PiotrowskA, Malgorzata KLIMEK, Beata Anna KLIMEK, Jerzy \\ KRUK, and Barbara PLYTYCZ
}

Accepted May 19, 2011

\begin{abstract}
Podolak A., Piotrowska E., Klimek M., Klimek B.A., Kruk J., Plytycz B. 2011. Effects of nickel, zinc, and lead-contaminated soil on burrowing rate and coelomocytes of the earthworm, Allolobophora chlorotica. Folia biologica (Kraków) 59: 91-97.

We have shown previously that stubby worms Allolobophora chlorotica are sensitive to environmental stress, including metal-polluted soil. In order to discern the mechanisms of this sensitivity, adult (clitellate) Al. chlorotica were exposed in the laboratory to soil samples soaked with water (control) or Ni ( 1 and $2 \mathrm{mg} / \mathrm{kg}), \mathrm{Zn}(1.25$ and $2.5 \mathrm{~g} / \mathrm{kg}$ ) or Pb $(5$ and $10 \mathrm{~g} / \mathrm{kg})$ chlorides. Worms avoided contact with metal contaminants by prolonging burrowing time in metal-soaked samples, especially in the case of lead. Higher concentrations of the investigated metals were lethal for worms. During a 3 week exposure to lower metal concentrations, nickel and lead readily accumulated in the bodies of worms while zinc was efficiently regulated. However, body weights and numbers of non-invasively retrieved free coelomocytes (consisting of amoebocytes and riboflavin-loaded eleocytes) were significantly lower only in zinc-exposed worms. We assume that zinc regulation in worm bodies is more energy-demanding than nickel or lead bioaccumulation, thus this might be responsible for inhibition of the body gain and diminution of immunocompetent cells in zinc-exposed earthworms. Alternatively, missing free coelomocytes may actually be involved in $\mathrm{Zn}$ trafficking and removal through nephridia and/or in the formation of multicellular brown bodies, since metal can unbalance host/bacteria relationships.

Key words: Earthworm burrowing, coelomocytes, eleocytes, autofluorescence, riboflavin.

Agnieszka PODOLAK, Elzbieta PIOTROWSKA, Malgorzata KlIMEK, and Barbara PlytYCZ, Department of Evolutionary Immunobiology, Institute of Zoology, Jagiellonian University, R. Ingardena 6, 30-060 Kraków, Poland.

E-mail: barbara.plytycz@uj.edu.pl

Beata Anna KLIMEK, Institute of Environmental Sciences, Jagiellonian University, Gronostajowa 7, 30-387 Kraków, Poland.

Jerzy KRUK, Faculty of Biochemistry, Biophysics, and Biotechnology, Jagiellonian University, Gronostajowa 7, 30-387 Kraków, Poland.
\end{abstract}

Several experimental approaches have been developed on the use of earthworms as bioindicators of environmental quality (e.g. SPURGEON et al. 2003; STÜRZENBAUM et al. 2009). These include observations of earthworm behaviour (e.g. YEARDLEY et al. 1996; STEPHENSON et al. 1998; CAPOWIEZ et al. 2003; LANGDON et al. 2001, 2005; LOUREIRO et al. 2005; LUKKARI et al. 2005; OWOJORI \& REINECKE 2009) and tests of their immunocompetent cells, the coelomocytes, noninvasively retrieved from the coelomic cavity (e.g. PLYTYCZ et al. 2007). For the latter type of experiments earthworms can be collected in the field from unpolluted or metalliferous sites (PlYTYCZ et al. 2009, 2010a, 2010b), or exposed in the laboratory to field-collected natural soil samples (HOMA et al. 2003; WIECZOREK-OLCHAWA et al. 2003; PLYTYCZ et al. 2009, 2010a, 2010b; PIOTROWSKA et al. 2010). To avoid antagonistic, additive, or synergistic effects of uncontrolled mixture of metals in natural soil, earthworms should be maintained in artificial or natural soil samples experimentally spiked with known concentrations of heavy metals (e.g. KWADRANS et al. 2008; DUTKIEWICZ et al. 2009), however, metal bioavailability may still be affected by soil properties. Thus, for comparative studies of metal toxicity, exposure to filter papers soaked with metal ions (HOMA et al. 2005, 2007, 2010; OlCHAWA et al. 2006; PLYTYCZ et al. 2011a) has been adapted from OECD (1984). 
The effects of metals on earthworm coelomocytes are known from studies performed on coelomocytes of Eisenia fetida (HOMA et al. 2005, 2007 ) and Dendrobaena veneta (OLCHAWA et al. 2006) as these species are easy to maintain in laboratory conditions. Nevertheless, it is crucial to study also more ecologically relevant species such as Lumbricus rubellus (PLYTYCZ et al. 2010b), Aporrectodea caliginosa (DUTKIEWICZ et al. 2009), Dendrodrilus rubidus (PLYTYCZ et al. 2009, 2010a) and Allolobophora chlorotica (HoMA et al. 2003, 2007, 2010; KUREK et al. 2007; PIOTROWSKA et al. 2010). Coelomocytes can be quantitatively retrieved from the coelomic cavity, counted, and analysed by flow cytometry in respect to the percentage of autofluorescent chloragocyte-derived eleocytes (e.g. CHOLEWA et al. 2006), accumulating riboflavin in their granular chloragosomes (KOZIOL et al. 2006; PLYTYCZ et al. 2007). The amount of riboflavin in coelomocyte lysates may be quantified by spectrofluorometry (PLYTYCZ et al. 2006). Species with a high content of riboflavin-loaded eleocytes, such as Al. chlorotica, E. andrei, D. veneta, are especially suitable for the detection of toxic factors (PLYTYCZ et al. 2011b).

Coelomocytes of the stubby worm, Al. chlorot$i c a$, are well-characterised (KUREK \& PLYTYCZ 2003; KUREK et al. 2007) and sensitive to metals both in animals exposed to filter papers soaked with metal chlorides (HOMA et al. 2005, 2007, 2010) and to natural soil samples from the metalliferous areas of Wales polluted mainly with zinc, lead and nickel, at mean concentrations equal to $15.4,9.1$, and $3.6 \mathrm{~g} / \mathrm{kg}$, respectively (PIOTROWSKA et al. 2010). Therefore the aim of the present work was to compare the effects of 3-week exposure of $\mathrm{Al}$. chlorotica to soil samples soaked with high concentrations of zinc, lead, and nickel chlorides on coelomocytes retrieved at the end of the experimental period, with special emphasis on cell counts and riboflavin content. Additionally, earthworm behaviour in contact with contaminated soil was monitored and burrowing rate was recorded. Metal accumulation in worm bodies over a 3-week exposure period was also established.

\section{Material and Methods}

\section{Earthworms}

Adult (sexually mature with a well-developed clitellum) earthworms Allolobophora chlorotica were collected by manual digging and hand sorting of soil from the experimental garden of the Institute of Zoology of the Jagiellonian University. All earthworms were maintained in the laboratory at $16-17^{\circ} \mathrm{C}$ and $12: 12$ light/darkness regime, and fed on mixed food (flour, boiled tealeaves, mouse feed and powdered milk) twice per week. Experiments were performed during the summer. Groups of animals (5 individuals per $0.2 \mathrm{~kg}$ soil samples per each group) were maintained in plastic boxes covered with perforated lids.

\section{Soil samples}

Air-dried metal-free soil purchased from a commercial supplier (PPUH BIOVITA, Tenczynek) was spiked either with distilled water (control) or with one of the heavy metal chlorides (Sigma) at the nominal final concentrations: $\mathrm{Ni}(1$ and 2 $\mathrm{g} / \mathrm{kg}), \mathrm{Zn}(1.25$ and $2.5 \mathrm{~g} / \mathrm{kg}), \mathrm{Pb}(5$ and $10 \mathrm{~g} / \mathrm{kg}$ ). Soils samples were allowed to equilibrate for 24 hours before being used in the experiments.

\section{Soil burrowing rate}

At the start of experiments, earthworms of similar body weights were placed on the top of the control or metal-soaked soil surface and the time necessary for their complete disappearance from the upper surface of the soil (time of burrowing) was measured and expressed in minutes.

\section{Coelomocyte retrieval}

At the end of the experiments, the surviving earthworms were stimulated for 1 minute with a $4.5 \mathrm{~V}$ electrical current to expel coelomic fluid with coelomocytes through the dorsal pores, according to a procedure described previously (PLYTYCZ et al. 2006). Briefly, after weighing, washing and dry-blotting, the earthworms were placed individually in Petri dishes containing $3 \mathrm{ml}$ of extrusion fluid $(0.9 \%$ saline supplemented with $2 \mathrm{~g} / \mathrm{l}$ EDTA (Sigma) to prevent cell aggregation). Extruded coelomocytes were counted in a haemocytometer. Cell suspension $(2 \mathrm{ml})$ was lysed in $2 \%$ Triton (Sigma) and used for spectrofluorometric detection/measurement of riboflavin content while the remaining parts of samples were fixed in $2 \%$ formalin and used for flow cytometric detection of autofluorescent eleocytes.

\section{Flow cytometric measurements and analysis}

Samples of formalin-fixed coelomocytes were analysed with a FACSCalibur flow cytometer (BD Biosciences). 10000 thresholded events per worm sample were collected and analysed on the basis of their forward scatter (FS) (for cell size) and sideward scatter (SS) (cell complexity) properties. Fluorescence FL1 (for autofluorescence) (emission $530 \mathrm{~nm}$; excitation $488 \mathrm{~nm}$ ) was recorded. The resulting files were analysed using WinMDI 2.8 software (http://facs.scripps.edu) by producing density plots of FL1 autofluorescence. 
Spectrofluorometric measurements and analysis

Measurements were done on a Perkin-Elmer spectrofluorometer LS50B (Beaconsfiled, Buckinghamshire, United Kingdom) in 2-ml of 2\% Triton coelomocyte lysates in cuvettes with an excitation slit of $5 \mathrm{~nm}$ and an emission slit of 5 or $10 \mathrm{~nm}$. Excitation spectra were recorded between $300-510 \mathrm{~nm}(\lambda=525 \mathrm{~nm})$, while emission spectra were recorded between $390-700 \mathrm{~nm}(\lambda=370 \mathrm{~nm})$. Excitation of a sample at $370 \mathrm{~nm}$ resulted in an emission spectrum with a maximum at $525 \mathrm{~nm}$, while monitoring of fluorescence at $525 \mathrm{~nm}$ provided the excitation spectra with maxima at 370 $\mathrm{nm}$ and $450 \mathrm{~nm}$. Spectrofluorometric analysis of earthworm coelomocyte samples was performed as previously described (CYGAL et al. 2007).

\section{Metal content in whole earthworm bodies}

Earthworms were left on wet filter papers in Petri dishes for $48 \mathrm{~h}$ to depurate. Metal accumulation was measured in whole worm bodies using an atomic absorption spectrophotometer (Aanalyst 800 , Perkin-Elmer) as described in detail in previous papers for $\mathrm{Cd}, \mathrm{Cu}$, and $\mathrm{Pb}$ exposure (HOMA et al. 2003) or Ni-exposure (BEDNARSKA \& LASKOWSKI 2008).

\section{Statistical analysis}

Results were expressed as means \pm standard errors. Differences between means were determined by a Mann-Whitney test with significance at $\mathrm{P}<0.05$, using Microsoft Excel v. 97.

a

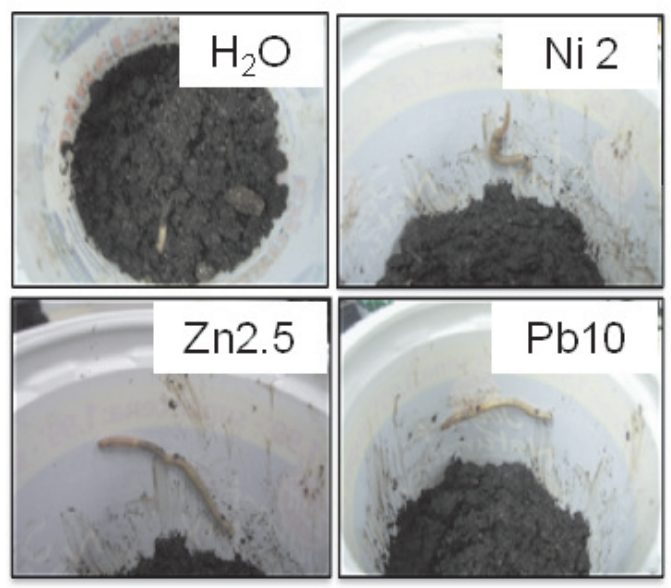

\section{Results}

Worm burrowing rate and survival (Fig. 1)

The behaviour of Al. chlorotica differed depending on whether worms were put on the surface of water-soaked uncontaminated soil or on metal chloride-soaked soil. In containers with the control soil, earthworms started burrowing directly after introduction, whereas burrowing was delayed in containers with metal-soaked soils. In higher metal concentrations worms exhibited side-track "searching" behavior. This was especially drastic in the case of higher metal concentrations when worms tried to avoid contact with soil and tried to escape from containers (Fig. 1a), especially from those containing soil soaked with lead at $10 \mathrm{~g} / \mathrm{kg}$, when time of burrowing was longer than 30 minutes.

Figure $1 \mathrm{~b}$ shows the mean times of burrowing in the control and metal-polluted soil samples. Burrowing in polluted soil was always prolonged in comparison with the control group, especially in contact with higher metal chloride concentration. In the case of lead the differences versus control were statistically significant.

All worms in containers with higher metal concentrations $(2,2.5$, and $10 \mathrm{~g} / \mathrm{kg}$ of $\mathrm{Ni}, \mathrm{Zn}$, and $\mathrm{Pb}$, respectively) died during the first or second week of exposure. Due to the high mortality after exposure to high metal concentrations in soil, data on metal accumulation, body weights and coelomocyteconnected parameters after 3-week exposure concern only Al. chlorotica maintained in soil with

b

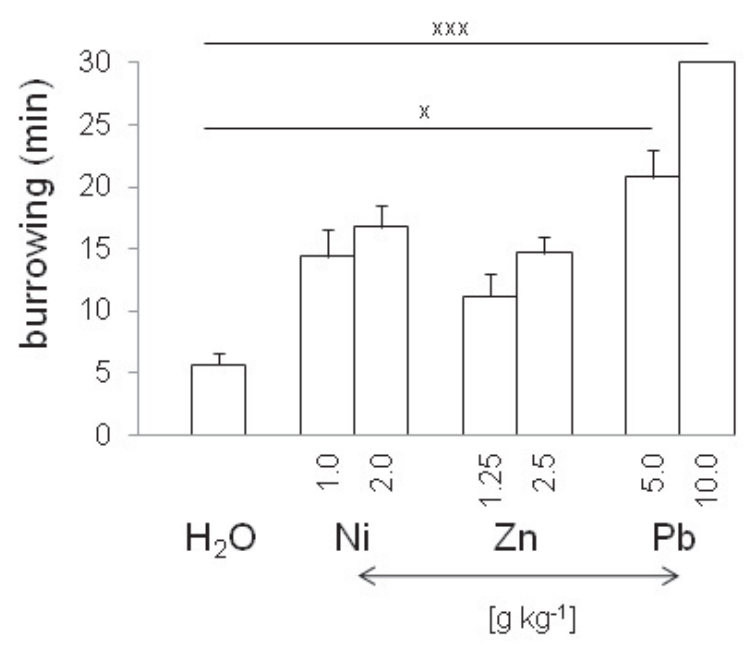

Fig. 1. Avoidance behaviour and burrowing rate of Allolobophora chlorotica in contact with soil samples soaked with water ( $\mathrm{H}_{2} \mathrm{O}$ - controls) or metal chlorides: $\mathrm{Ni}\left(1\right.$ and $\left.2 \mathrm{~g} \mathrm{~kg}^{-1}\right), \mathrm{Zn}\left(1.25\right.$ and $\left.2.50 \mathrm{~g} \mathrm{~kg}^{-1}\right)$ and $\mathrm{Pb}\left(5\right.$ and $\left.10 \mathrm{~g} \mathrm{~kg}^{-1}\right)$; a) typical examples of burrowing in the control soil and avoidance behaviour in soil samples soaked with Ni, Zn, Pb at 2.0,2.5, and $10.0 \mathrm{~g} \mathrm{~kg}^{-1}$, respectively; b) time of burrowing [minutes] measured from the contact with particular soil sample untill complete worm disappearance from the soil surface. Means + SE, 5 worms per group. Asterisks at means statistically significantly different from those of the water-soaked group ( $\mathrm{P}<0.05$ according to Mann-Whitney's test). 
lower metal content, i.e. $1,1,25$, and $5 \mathrm{~g} / \mathrm{kg}$ of $\mathrm{Ni}$, $\mathrm{Zn}$, and $\mathrm{Pb}$, respectively (Figs $2 \& 3$ ).

Metal accumulation in whole earthworm bodies (Fig. 2)

At the end of exposure to metal-soaked or control soil samples, metal concentrations in Al. chlorotica bodies were significantly higher in worms kept in $\mathrm{Ni}$ and $\mathrm{Pb}$-soaked soils than in the control group. In contrast, $\mathrm{Zn}$ concentrations were similar in the whole bodies of the control worms and those exposed to Zn-soaked soil (Fig. 2).

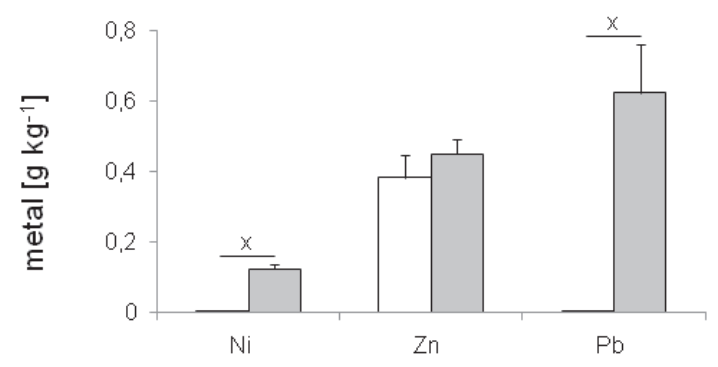

Fig. 2. Metal concentrations ( $\mathrm{g} \mathrm{kg}^{-1}$ dry weight) in whole bodies of Allolobophora chlorotica maintained for 3 weeks in soil samples soaked with water only (empty bars) or metal chlorides at $1.0,1.25$, and $5 \mathrm{~g} \mathrm{~kg}^{-1}$ dry soil weight for $\mathrm{Ni}, \mathrm{Zn}$, and $\mathrm{Pb}$, respectively (solid bars). Means $+\mathrm{SE}, 5$ worms per group. Asterisks at means statistically significantly different from those of the water-soaked group $(\mathrm{P}<0.05$ according to Mann-Whitney's test).
Earthworm body weights and coelomocytes (Fig. 3)

At the end of the experiments, body weights of Al. chlorotica kept in the Ni- and $\mathrm{Pb}$-chloride soaked soils were similar to their control counterparts. In contrast, body weights of worms exposed to $\mathrm{Zn}$-chloride were significantly lower (Fig. 3a). The number of coelomocytes extruded by electric shock was significantly reduced in Zn-exposed animals but was only slightly decreased in Ni- or $\mathrm{Pb}$-exposed worms (Fig. 3b). However, when coelomocyte numbers were adjusted per fresh body weight (i.e. expressed as $\mathrm{CN} / \mathrm{BW}$ ) the mean values did not differ significantly between the four treatment groups (Fig. 3c).

Flow cytometric analysis of coelomocyte samples confirmed the presence of both agranular amoebocytes and granular autofluorescent eleocytes. The latter exhibited strong FL-1 autofluorescence, similar to that described previously (HOMA et al. 2010). The percentages of autofluorescent eleocytes (E \%) were similar in the four treatment groups (Fig. 3d). The total number of eleocytes (EN) was lowest in Zn-exposed worms (Fig. 3e); the $\mathrm{Zn}$-induced effect became statistically insignificant in the EN/BW groups (Fig. 3f).

Spectrofluorometric analysis of coelomocyte lysates revealed riboflavin-specific emission and excitation spectra, as described previously (HOMA et al. 2010). The amount of riboflavin expressed in arbitrary units (RF [AU]) was significantly lower a)

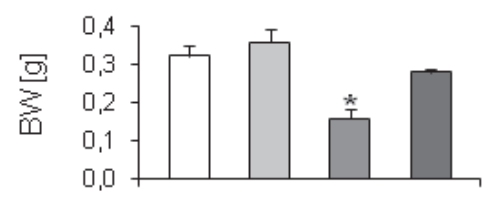

b)

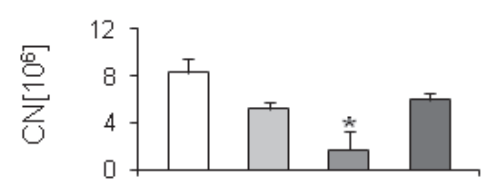

c)

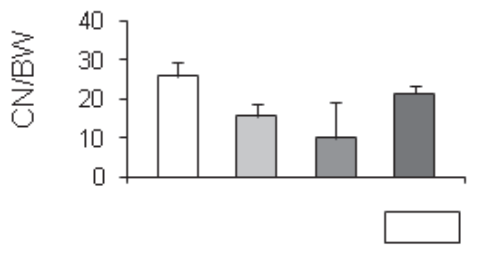

d)

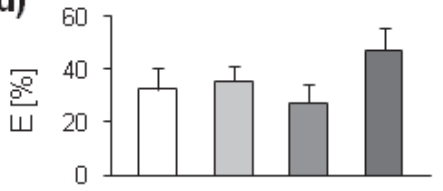

e)

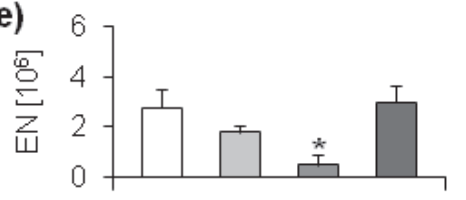

f)

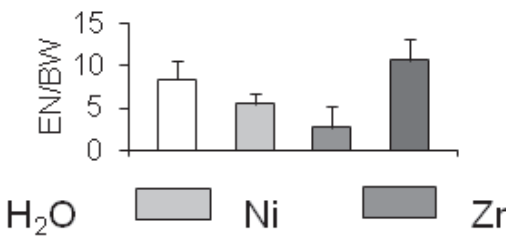

g)

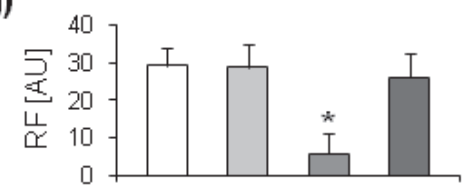

h)

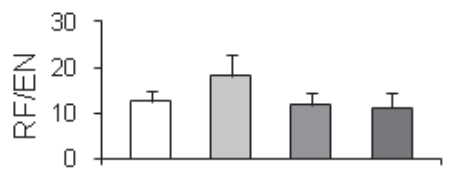

i)

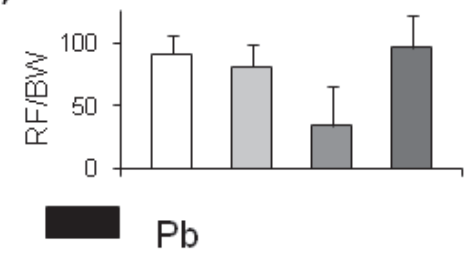

Fig. 3. Effects of soil samples soaked with water $\left(\mathrm{H}_{2} \mathrm{O}-\right.$ control group), $\mathrm{Ni}\left(1 \mathrm{~g} \mathrm{~kg}^{-1} \mathrm{~kg}\right), \mathrm{Zn}\left(1.25 \mathrm{~g} \mathrm{~kg}^{-1}\right)$, and Pb $\left(5 \mathrm{~g} \mathrm{~kg}^{-1}\right)$ on body weights (a) and coelomocytes (b-i) of Allolobophora chlorotica during 3-week exposure. a) fresh body weights (BW); b) total number of coelomocytes $(\mathrm{CN})$; c) coelomocytes per fresh body weight (CN/BW); d) percentages of eleocytes (E); e) total numbers of eleocytes (EN); f) eleocytes per body weight (EN/BW); g) riboflavin (RF) content in coelomocyte lysates in arbitrary units [AU]; $h$ ) riboflavin recalculated per eleocyte numbers (RF/EN); i) riboflavin per body weight (RF/BW); $\mathrm{X}+\mathrm{SE}$, $\mathrm{n}=$ samples from 4-5 worms per group. Asterisks at means statistically significantly different from those of the water-soaked group $(\mathrm{P}<0.05$ according to Mann-Whitney’s test $)$. 
in samples from $\mathrm{Zn}$-exposed worms than in the control and $\mathrm{Ni}$ - or $\mathrm{Pb}$-exposed groups of animals (Fig. 3g). However, when riboflavin content was adjusted to numbers of autofluorescent eleocytes $(\mathrm{RF} / \mathrm{EN})$ or to fresh body weights $(\mathrm{RF} / \mathrm{BW})$ the mean values did not differ significantly between groups (Fig. 3h, i).

\section{Discussion}

Earthworms can avoid soils containing elevated amounts of heavy metals and hazardous waste (YEARDLEY et al. 1996) as they have chemoreceptors in the prostomium and the sensory tubercle on the body (LAVERACK 1961; STEPHENSON et al. 1998). In most behavioural studies, earthworms are given a choice between adjacent soils, contaminant-free soil and a contaminant-bearing soil. Avoidance behaviour of earthworms to various chemicals has been reported by many authors (e.g. YEARDLEY et al. 1996; LANGDON et al. 2001, 2005; GARCIA 2008; EIJSACKERS et al. 2005; LOUREIRO et al. 2005; GARCIA et al. 2008; LUKKARI et al. 2005; OWOJORI \& REINECKE 2009). In some cases earthworms tolerate certain chemicals, i.e. organophosphate pesticides (HODGE et al. 2000) or lead nitrate (REINECKE et al. 2002). In several experiments earthworm burrowing rate (i.e. time taken to burrow into soil) was recorded (e.g. EIJSACKERS et al. 2005; LANGDON et al. 2001) while in others earthworm trajectories within soil were also reconstructed and measured (CAPOWIEZ et al. 2003).

Al. chlorotica is a soil-dwelling geophagous species which is typically found close to the soil surface when soil conditions are favourable but will burrow deeper to avoid extremes of temperature or dry soil at the surface (GERARD 1967). ELLIS et al. (2010) used a vertical arrangement of containers with control soil and soil contaminated with a toxic fungicide - carbendazim. Al. chlorotica avoided toxic fungicide-bearing soil samples in all instances except that when worms were put directly on the top of the polluted soil. In this case the majority remained in the toxic soil, perhaps due to impaired mobility caused by the neurotoxic effects of fungicide (ELLIS et al. 2010). Observations of Al. chlorotica from previous (PIOTROWSKA et al. 2010) and present experiments indicate that earthworms can also detect metal soil pollution and change accordingly their behaviour. The results fully confirmed that avoidance behaviour and burrowing rate are fast and simple screening tools to assess soil quality.

Nickel and lead accumulated significantly in worm bodies during the 3-week exposure whereas zinc accumulation was efficiently regulated. Nev- ertheless zinc exposure significantly inhibited weight gain. This corresponded with a significant decrease of total numbers of coelomocytes, among them riboflavin-loaded eleocytes, and as a consequence a significant decrease of riboflavin content in coelomocyte lysates.

Inhibition of weight gain in zinc-exposed worms may be putatively explained by the high energetic costs of efficient zinc regulation. Diminution of coelomocyte number in the extruded coelomic fluid may be connected with coelomocyte participation in $\mathrm{Zn}$ trafficking and removal through nephridia (STÜRZENBAUM et al. 2001; HOMA et al. 2005). Alternatively missing free coelomocytes may be involved in the formation of multicellular brown bodies encapsulating intracoelomic microbes (VALEMBOIS 1992, 1994).

We are unaware of studies on the energetic costs of metal regulation or bioaccumulation in earthworm bodies. Until now, the energetic costs of detoxification systems were explored in herbivores feeding on chemically defended host plants. In the case of the grain aphid, Sitobion avenae, reared on host plants with differing levels of hydroxamic acid, the energetic costs of detoxification were low (CASTANEDA et al. 2009). We assumed that zinc regulation in Al. chlorotica bodies was more energy-demanding than nickel or lead bioaccumulation.

In previous experiments, D. veneta (KWADRANS et al. 2008) and Aporrectodea caliginosa (DUTKIEWICZ et al. 2009) were maintained for 4 and 8 weeks, respectively, in soil samples soaked with $\mathrm{Cd}, \mathrm{Cu}, \mathrm{Pb}$, or Ni chlorides. Body weights of $D$. veneta were unaffected by 4-week metal exposure, but eleocyte numbers and riboflavin content were increased in $\mathrm{Pb}$ - and/or decreased in Niexposed groups of worms. In contrast, after 8week experiments on $A$. caliginosa, body weight gain was inhibited in all metal-exposed groups while coelomocyte number was significantly increased in $\mathrm{Pb}$-exposed worms. This indicates that the effects of metal soil pollution on the earthworm immune system are species-specific and do not always correspond with the general condition of worms. We may assume that effects of metal exposure on immunity are rather associated with the disrupted balance between the worm immune system and microbial impact from surrounding metal-polluted soil (SALICE \& ROESIJADI 2002; WIECZOREK-OLCHAWA et al. 2003; OLCHAWA et al. 2006).

The earthworm coelom is inhabited by a variety of prokaryotic and eukaryotic organisms, including bacteria, protozoans, fungi, and nematodes, which are effectively controlled by the immune system (FIELD et al. 2004). However, metal expo- 
sure can unbalance the host-bacteria relationship, as evidenced in $D$. veneta after 3-day exposure to filter paper soaked with water (controls) or metal $(\mathrm{Zn}, \mathrm{Cu}$, or $\mathrm{Cd})$ chlorides. Zn was efficiently regulated, while $\mathrm{Cu}$ and $\mathrm{Cd}$ accumulated in worm bodies. Numbers of coelomocytes were unaffected by $\mathrm{Zn}$ exposure but were significantly decreased in $\mathrm{Cu}$ and $\mathrm{Cd}$-exposed worms. In the same animals, the contents of bacteria in coleomic cavities increased in $\mathrm{Zn}$ and $\mathrm{Cu}$-exposed worms, but decreased in Cd-exposed animals. Moreover, when coelom-derived bacteria were in vitro incubated in the presence of metal chlorides, bacterial growth was supported by zinc ions but was significantly or almost completely inhibited by $\mathrm{Cu}$ and $\mathrm{Cd}$ ions, respectively (OLCHAWA et al. 2006). For the experimental conditions used in present experiments on Al. chlorotica, zinc contamination acted in favour of microbes inhabiting the soil and the earthworm coelomic cavity, leading to impaired body mass gain and a decrease in free coelomocyte numbers. In contrast, $\mathrm{Ni}$ and $\mathrm{Pb}$ soil pollution may reduce the bacterial content of soil and worm bodies, therefore the metal burden did not impair worm body weights and their immunocompetent cells.

In conclusion, a soil avoidance test and burrowing rate of $\mathrm{Al}$. chlorotica can be used as a quick preliminary method to determine the potential contamination of soil. Metals may be either regulated $(\mathrm{Zn})$ or accumulated $(\mathrm{Ni}, \mathrm{Pb})$ in worm bodies, with or without deleterious effects on body weights and immunocompetent cells, putatively due to their differential impact on soil- and coelom-inhabiting microbes.

\section{References}

BEDNARSKA A., LASKOWSKI R. 2008. Effects of nickel and temperature on the ground beetle Pterostichus oblongopunctatus (Coleoptera: Carabidae). Ecotoxicology 17: 189-198.

Capowiez Y., Rault M., Mazzia Ch., Belzunces L. 2003. Earthworm behaviour as a biomarker - a case study using imidacloprid. Pedobiologia 47: 542-547.

Castańeda L.E., Figueroa C. C., Fuentes-Contreras E. Niemeyer H. M., Nespolo R. F. 2009. Energetic costs of detoxification systems in herbivores feeding on chemically defended host plants: a correlational study in the grain aphid Sitobion avenae. J. Exp. Biol. 212: 1185-1190.

Cholewa J., Feeney G. P., O'Reilly M., Sturzenbaum S. R., MoRgan A. J., PlyTyCZ B. 2006. Autofluorescence in eleocytes of some earthworm species. Fol. Histochem. Cytobiol. 44: 65-71.

Cygal M., Lis U., KRUK J., Plytycz B. 2007. Coelomocytes and fluorophores of the earthworm Dendrobaena veneta raised at different ambient temperatures. Acta Biol. Crac. Ser. Zool. 49: 5-11.

Dutkiewicz R., KLimek M., Klimek B., Stefanowicz A.M., PŁYTYCZ B. 2009. Effects of cadmium, copper, lead or nickel-contaminated soil on amoebocytes of the earthworm, Aporrectodea caliginosa. Acta Biol. Crac. Ser. Zool. 51: 73-79.
EiJSACKERS E., BeneKe P., MABOETA M., LOUW J. P. E., REINECKE A. J. 2005. The implications of copper fungicide usage in vineyards fro eathworm activity and resulting sustainable soil quality. Ecotox. Environ. Safe. 62: 99-111.

Ellis S. R., HodSON M. E., WEGE P. 2010. The soil-dwelling earthworm Allolobophora chlorotica modifies its burrowing behavior in response to carbendazim applications. Ecotox. Environ. Safe. 73: 1424-1428.

Field S. G., KuRTZ J., COOPER E. L., Michiels N. N. 2004. Evaluation of an innate immune reaction to papasites in earthworms. J. Invertebr. Pathol. 86: 45-49.

GARCIA M., RÖMBKE J., TORRES DE BRITO M., SCHEFFCZYK A. 2008. Effect of three pesticides on the avoidance behavior of earthworms on laboratory tests performed under temperate and tropical conditions. Environ. Pollut. 153: 450-456.

GERARD B. M. 1967. Factors affecting earthworms in pastures. J. Anim. Ecol. 36:235-252.

Hodge S., Webster K. M., Booth L., Hepplethwaite V., O'HALLORAN K. 2000. Nonavoidance of organophosphate insecticides by the earthworm Aporrectodea caliginosa (Lumbricidae). Soil Biol. Biochem. 32: 425-428.

Homa J., KlimeK M., KRUK J., COCQUERELle C., VANDENBULCKE F., PLYTYCZ B. 2010. Metal-specific effects on metallothionein gene induction and riboflavin content in coelomocytes of the stubby earthworm Allolobophora chlorotica exposed dermally to metal chlorides. Ecotox. Environ. Safe. 73: 1937-1943.

Homa J., NikLińska M., PŁyTYCZ B. 2003. Effect of heavy metals on coelomocytes of the earthworm Allolobophora chlorotica. Pedobiologia 47: 640-645.

Homa J., Olchawa E., Sturzenbaum S. R., Morgan A. J., PLYTYCZ B. 2005. Early-phase immunodetection of metallothionein and heat shock proteins in extruded earthworm coelomocytes after dermal exposure to metal ions. Environ. Pollut. 135: 275-280.

Homa J., Stürzenbaum S. R., Morgan A. J., Plytycz B. 2007. Disrupted homeostasis in coelomocytes of Eisenia fetida and Allolobophora chlorotica exposed dermally to heavy metals. Eur. J. Soil Biol. 43: 273-280.

Koziol B., MARKowicz M., KRUK J., Plytycz B. 2006. Riboflavin as a source of autofluorescence in Eisenia fetida coelomocytes. Photoch. Photobiol. 82: 570-573.

Kurek A., Homa J., KauschKe E., Plytycz B. 2007. Characteristics of coelomocytes of the stubby earthworm, Allolobophora chlorotica (Sav.). Eur. J. Soil Biol. 43: 121-126.

KUREK A., PlytyCZ B. 2003. Annual changes in coelomocytes of four earthworm species. Pedobiologia 47: 689-701.

KWADRANS A., LiTWA J., WOŁOSZCZAKIEWICZ S., KSIEŻARCZYK E., KLIMEK M., DUCHNOWSKI M., KRUK J., PŁYTYCZ B. 2008. Changes in coelomocytes of the earthworm, Dendrobaena veneta, exposed to cadmium, copper, lead or nickelcontaminated soil. Acta Biol. Crac. Ser. Zool. 49: 57-62.

Langdon C. J., Piearce T. G., Meharg A. A., Semple K. T. 2001. Survival and behavious of the earthworms Lumbricus rubellus and Dendrodrilus rubidus from aresemantecontaminated and non-contaminated sites. Soil Biol. Biochem. 33: 1239-1244.

Langdon C. L., Hodson M. E., ARnold R. E., Black S. 2005. Survival, Pb-uptake and behaviour of three species of earthworm in $\mathrm{Pb}$ treated soils determined using an OECDstyle toxicity test and a soil avoidance test. Environ. Pollut. 138: 368-375.

LAVERACK M. S. 1961. Tactile and chemical perception in earthworms. II. Responses to acid pH solutions. Comp. Biochem. Physiol. 2: 22-34.

Loureiro S., Soares A. M. V. M., Nogueira A. J. A. 2005. Terrestrial avoidance behavior tests as screening tool to assess soil contamination. Environ. Pollut. 138: 121-131.

LUKKARI T., HAIMI J. 2005. Avoidance of $\mathrm{Cu}-$ and $\mathrm{Zn}-$ contaminated soil by three ecologically different earthworm species. Ecotox. Environ. Safe. 62: 35-41. 
OECD, Guidelines for the testing of chemicals. No. 207. Earthworm acute toxicity tests. Adopted April 4. 1984.

Olchawa E., BZOWSKA M., STÜRZENBAUM S. R., MORGAN A. J., PŁYTYCZ B. 2006. Heavy metals affect the coelomocyte-bacteria balance in earthworms: Environmental interactions between abiotic and biotic stressors. Environ. Pollut. 142: 373-381.

OWOJORI O. J., REINECKE A. J. 2009. Avoidance behaviour of two eco-physiologically different earthworms (Eisenia fetida and Aporrectodea caliginosa) in natural and artificial saline soils. Chemosphere 75: 279-283.

Piotrowska E., Podolak A., Klimek M., Klimek B. A., KRUK J., PLYTYCZ B. 2010. Effects of metalliferous soil on coelomocytes from ecophysiologically contrasting lumbricid species. Acta Biol. Cracov. Ser. Zool. 52: 5-17.

Plytycz B., Kielbasa E., Grebosz A., Duchnowski M., KRUK J., MORGAN A. J. 2010a. Riboflavin mobilization from eleocyte stores in the earthworm Dendrodrilus rubidus aerially-contaminated Ni-smelter soil. Chemosphere $\mathbf{8 2}$ : 199-205.

Plytycz B., KlimeK M., Homa J., MAZUR A. I., KRUK J., MORGAN A. J. 2011a. Species-specific sensitivity of earthworm coelomocytes to dermal metal $(\mathrm{Cd}, \mathrm{Cu}, \mathrm{Ni}, \mathrm{Pb}, \mathrm{Zn})$ exposures: tailoring biomarker assays to the immunocyte characteristics of individual lumbricid species. Pedobiologia (in press)

Plytycz B., Klimek M., Klimek B. A., Szymanski W., KRUK J., MORGAN A. J. 2011b. Riboflavin content in the coelomocytes of contrasting earthworm species is differentially affected by edaphic variables including organic matter and metal content. Pedobiologia (in press).

Plytycz B., Lis-Molenda U., Cygal M., Kielbasa E., Grebosz A., DuCHNOWSKI M., ANDRE J., MORGAN A. J. 2009. Riboflavin content of coelomocytes in earthworm (Dendrodrilus rubidus) field populations as a molecular biomarker of soil metal pollution. Environ. Pollut. 157: 3042-3050.

Plytycz B., Cygal M., Lis-Molenda U., KlimeK M., Mazur A. J., Duchnowski M., Morgan A. J. 2010b. Characteristics of immune-competent amoebocytes noninvasively retrieved from populations of the sentinel earth worm Lumbricus rubellus (Annelida; Oligochaeta; Lumbricidae) inhabiting metal polluted field soils. Ecotox. Environ. Safe. DOI: 10.1016/j.ecoenv.2010.10.028.

Plytycz B., Homa J., Koziol B., Rozanowska M., MorGAN A. J. 2006. Riboflavin content in autofluorescent earthworm coelomocytes is species-specific. Fol. Histochem. Cytobiol. 44: 275-280.
Plytycz B., KlimeK M., Homa J., Tylko G., KolACZKOWSKA E. 2007. Flow cytometric measurement of neutral red accumulation in earthworm coelomocytes: Novel assay for studies on heavy metal exposure. Eur. J. Soil Biol. 43: 116-120.

Reinecke A. J., Maboeta M. S., Vermeulen L. A., ReiNECKE S. A. 2002. Assessment of lead nitrate and mancozeb toxicity in earthworms using the avoidance response. Bull. Environ. Contam. Toxicol. 68: 779-786.

SALICE C.J., RoESIJADI G. 2002. Resistance to cadmium and parasite infection are inversely related in two strains of a freshwater gastropod. Environ. Toxicol. Chem. 21: 1398-1403.

Spurgeon D. J., WeEKs J. M., van Gestel C. A. M. 2003. A summary of eleven years progress in earthworm ecotoxicology. Pedobiologia 47: 588-606.

STEPHENSON G. L., KAUSHIK A., KAUSHIK N. K., SOLOMON K. R., SteEle T., SCROGgins R. P. 1998. Use of an avoidance-response test to assess toxicity of contaminated soils to earthworms. (In: Advances in Earthworm Ecotoxicology. S. C.SHEPPARD, J. D. BEMBRIDGE, M. HOLMSTRUP and L. POSTHUMA SETAC. Pensacoloa): 67-81.

STÜRZENBAUM S. R., WinTERS C., Galay M., Morgan A. J., KILLE P. 2001. Metal ion trafficking in earthworms. Identification of a cadmium-specific metallothionein. J. Biol. Chem. 276: 34013-34018.

StÜrzenbaum S. R., Andre J., Kille P., Morgan A. J. 2009. Darwin and his earthworms: genomics, proteomics and metabolomics. Proc. R. Soc. B. 276: 789-797.

VALEMBOIS P., LASSČGUES M., RoCH P. 1992. Formation of brown bodies in the coelomic cavity of the earthworm Eisenia fetida andrei and attendant changes in shape and adhesive capacity of constitutive cells. Dev. Comp. Immunol. 16: 95-101.

VALEMBois P., Seymour J., LASSČGUes M. 1994. Evidence of lipofuscin and melanin in the brown body of the earthworm Eisenia fetida andrei. Cell Tissue Res. 227: 183-188.

WieczoreK-Olchawa E., NikLinsKa M., MiedZOBRODZKI J., PLYTYCZ B. 2003. Effects of temperature and soil pollutions on the presence of bacteria, coelomocytes and brown bodies in coelomic fluid of Dendrobaena veneta. Pedobiologia 47: 702-709.

YEARDLEY Jr. R. B., LAZORCHAk J. M., GAST L. C. 1996. The potential of an earthworm avoidance test for evaluation of hazardous waste sites. Environ. Toxicol. Chemistry. 15: 1532-1537. 